\title{
THE RELATION BETWEEN AMERICAN CHOICE OF LAW AND FEDERAL COMMON LAW
}

\author{
Donald T. Trautman*
}

\section{INTRODUCTION}

The current literature on choice of law offers an abundance of new "approaches" to explain and give structure to the now fairly widespread rejection by courts of the simple and rigid systematics of Professor Beale and his 1934 Restatement of Conflict of Laws. My own efforts, largely in association with my colleague Arthur von Mehren, ${ }^{1}$ have led me to think that one of the central issues is the basic premise which we all-Professor Beale ${ }^{2}$ as well as those who follow-have been using. That premise is that the problem is one of conflict or choice between or among the competing rules and policies of coordinate jurisdictions, states or nations. In what follows, I propose a substitute for that premise and suggest what $I$ hope is a more constructive way of stating the problem.

As I shall attempt to state more precisely at a later point in this paper, the proposal is that a more congenial approach might be to ask whether a normal substantive-law rule exists, one widely shared in the legal world to which the concerned jurisdictions (including the forum) belong, and whether the policies of particular concerned jurisdictions with views departing from that norm are strong enough and relevant enough to justify application of their divergent views in the particular case. Although I am not clear that there

\footnotetext{
* Professor, Harvard University Law School.

1. Our joint views were first brought together in A. von Mehren \& D. Trautman, The Law of Multistate Problems (1965) [hereinafter cited as von Mehren \& Trautman.] For subsequent individual writings see, e.g., von Mehren, Comment: Special Substantive Rules for Multistate Problems: Their Role and Significance in Contemporary Choice of Law Methodology, 88 HARv. L. REv. 347 (1974); von Mehren, Recent Trends in Choice-of-Law Methodology, 60 Cornell L. Rev. 927 (1975); Trautman, Kell v. Henderson: A Comment, 67 Colum. L. Rev. 465 (1967); Trautman, Comment on Reich v. Purcell, 15 U.C.L.A. L. Rev. 618 (1968); Trautman, Rule or Reason in Choice of Law: A Comment on Neumeier, 1 VT. L. REv. 1 (1976).

2. Professor Beale opted for "Conflict of Laws" on a pragmatic basis. "To be accurate the term must be long and clumsy; inexcusable vices in a proper name. . . In this dilemma we choose the term which came first into use, and was made familiar to Anglo-American ears by Story's great book, and by the later works of Wharton, Dicey, and Minor. One can do no better, in explaining his choice of this title, than quote the wise and witty words of Vareilles-Sommières. [Footnotes omitted.] "The warlike expression "Conflict of Laws" is used to describe the pacific work of setting by fixed bounds the line of separation between two legislative jurisdictions. The only conflict is among the legal authors who are doing this work. Yet since the expression is consecrated by good use and is simple we may well make use of it.' " I J. BEALE, A TREATISE ON THE Conflict of LAws 15 (1935).
} 
need be a limitation of this approach so as to include only interstate cases in the United States and to exclude international multistate cases, paradoxically enough some of the difficulty in the way of acceptance of such an approach is peculiarly of American manufacture; for that reason, I have devoted some of this paper to developments in federal common law which have served to overcome related difficulties in other areas and, if properly understood, should support my view in the area of choice of law. Further, I believe that the greater fluidity and resilience of our thinking about choice of law, as well as the greater pressure toward homogeneity in our substantive law, make the approach one for which the United States is perhaps more ready than are other countries. I am not prepared, however, to exclude use of the approach in international cases.

\section{I}

In our casebook presentation of a large number of cases in diverse areas in which an apparently concerned jurisdiction applies a rule other than the rule applicable to wholly domestic cases in that jurisdiction, Professor von Mehren and I have adopted the term "regulating rule" to refer to the rule so chosen. ${ }^{3}$ We have suggested that a concerned jurisdiction's "regulating rule" may be either the rule of some other jurisdiction or a rule specially fashioned for the multistate situation. To explain why a concerned jurisdiction may adopt a regulating rule differing from the rule it would apply to a wholly domestic case continues to be a complicated and perplexing matter.

In the past we described many of such cases as ones in which the jurisdiction's multistate policies outweigh its domestic-law concerns, multistate policies being those which reflect the needs of the community of jurisdictions involved. A more complete statement might be that a concerned jurisdiction not only weighs its own domestic-law policies against the domestic-law policies of other concerned jurisdictions, but takes into account, and on occasion makes decisive, the requirements of the multistate system, ${ }^{4}$ a system which may be thought to exist in fact, or whose existence is posited as an aid in thinking about proper resolution of the given multistate problem. The rule which comes to be used may then be described as a reformulated domestic-law rule, the rule of another jurisdiction (reformulated if necessary), or a specially fashioned multistate rule. On occasion, a particular case can be, or could have been, viewed as involving more than one of these possibilities. A good example is Bernkrant v. Fowler, ${ }^{5}$ that celebrated California decision written by Chief Justice Traynor allowing enforcement, in the face of the California statute of

3. von MEHREN \& Trautman, supra note 1, at 215.

4. Restatement (Second) of Conflict of Laws $\$ 6(2)(a)$ recognizes these requirements as a proper factor for consideration in choice of law.

5. 55 Cal. 2d 588, 360 P.2d 906 (1961). 
frauds, of a California decedent's oral promise to provide in his will for forgiveness of the remaining indebtedness of Nevada debtors in connection with their purchase of his Nevada property. An analysis of California domestic-law policy might have shown weakness in the evidentiary and cautionary policies underlying the statute of frauds. That weakness might have been such as to justify reformulation of the law even for a wholly domestic case presenting strong countervailing equitable considerations ${ }^{6}$ or involving extrinsic indications that the asserted promise had in fact been made. ${ }^{7}$ Even if the court was not prepared-and it was not-to reformulate the rule for wholly domestic cases ${ }^{8}$ these circumstances would plainly justify moderation in thinking about the application of domestic-law policy in the multistate case; ${ }^{9}$ the court could then find the policy less compelling, when it is examined in the light of the concerns of other jurisdictions, of multistate concerns for the transaction that spills over jurisdictional boundaries and is therefore less clearly subject to any one jurisdiction's laws, and of domestic-law policies in the forum that are subordinated in the wholly domestic case but may regain strength upon reexamination of their relevance in light of the multistate concerns and the concerns of another jurisdiction. It is more in this spirit, we believe, that Justice Traynor disposed of the problem in Bernkrant $v$. Fowler; he pointed to the contractual policies of Nevada tending toward validating such arrangements, the difficulties of a California choice-of-law rule for multistate cases that might hold the question of governing law in abeyance until the promisor's last domicile was fixed, and the hitherto subordinated California policies-shared with Nevada-of validating contractual arrangements.

An unsettling difficulty with this solution, which it will be observed purports to work accommodations out of the various policies held by the two jurisdictions involved, is the anomalous role of the court in weighing the strength of policy. Two distinct kinds of policy-weighing occur. The court assesses the strength of its own jurisdiction's various policies, although presumably they have been included in the calculus of a legislative determination, as here with the local Statute of Frauds or Statute of Wills, that usually does not but may say something about the statute's intended scope. It also assesses

6. See gemerally 1 ScotT on Trusts $\$ 55.0$ (3d ed. 1967).

7. There is some indication that the promise was in fact made. Although Justice Traynor does not elaborate, he painstakingly recites the facts, among which is the absence, in renegotiation of the mortgage, of a right which the debtors previously had to subordinate the promisor's mortgage to a deed of trust they might execute to secure a construction loan. It might be inferred that the quid pro quo for relinquishing the right to subordinate was the promise to forgive the remaining indebtedness.

8. $C f$. A. von Mehren \& J. Gordley, The Civil Law System 1129-31 (2d ed. 1977); von Mehren \& Trautman, supra note 1 , at 438-39, 469-71.

9. Long ago it was pointed out that in the multistate case, an opportunity is presented for a half-step toward reformulation of the domestic-law rule. See Freund, Chief Justice Stone and the Conflict of Laws, 59 Harv. L. Rev. 1210, 1224-1225 (1946); id. at 1216. Cf. von Mehren \& Trautman, supra note 1 , at 600 n.17. 
the weight to be given to the policies of a co-ordinate jurisdiction. No apparent guidelines exist for conducting these two clearly distinct, but equally nebulous, weighing processes. ${ }^{10}$ This anomaly is identifiable in many other cases involving the rejection by a concerned jurisdiction of its domestic-law rule and deference to another jurisdiction's concerns or to its own multistate concerns that conflict with its domestic-law concerns. ${ }^{11}$ Professor Currie's recognition that a concerned jurisdiction should use moderation and restraint in applying its domestic-law rules was at best an uneasy departure from his preference for forum law because of the absence of any firm footing in recognized institutional sources ${ }^{12}$ for such a departure and the undoubted opening to untrammeled judicial discretion that it represented.

These obstacles are ones which the courts today nevertheless seem almost eager to face, in part because they provide relief from the more than occasional irrationality and injustice of simpler approaches. Analysis of the multistate policies has been sparse; in our book, we attempt to catalogue what multistate policies are apparently at work in the cases today. ${ }^{13}$ In particular there are policies of the facilitation of multistate activity (which at a minimum operates to prevent the capricious interference with multistate activity that might result from the unexpected application of unusual rules having no policy relevant to the activity ${ }^{14}$ ), of evenhandedness and of administrability of the law. We have sought to explain that these are policies that might appropriately be held by the constituent jurisdictions of a multistate community, in recognition of the obvious needs of an ad hoc interstate order constructed for the individual case by the court encountering a multistate problem.

\section{II}

At least for communities not bound together by a federal system, it is understandable and perhaps inevitable that thinking about choice of law should have begun in terms of the clash of interests of equal independent sovereigns. It is also understandable in that setting that courts only later

10. Cf. Freund, supra note 9 , at $\mathbf{1 2 1 5}$.

11. We collect a number of such cases in our casebook, among the most familiar of which are Bernkrant v. Fowler, supra note 5; Shannon v. Irving Trust Co., 275 N.Y. 95, 9 N.E.2d 792 (1937), described in the text at note 54 infra; Siegelman v. Cunard White Star Ltd., 221 F.2d 189 (2d Cir. 1955), described in the text at note 55 infra; People v. One 1953 Ford Victoria, 48 Cal. 2d 595, 311 P.2d 480 (1957) (California statute calling for forfeiture of conditional vendor's interest in automobile seized for transportation of narcotics if vendor failed to make prescribed character examination of vendee not applied to Texas vendor who could not be expected to know California law); and Milliken v. Pratt, 125 Mass. 374 (1878) (Massachusetts protective policy for married woman not applied to Massachusetts wife's guaranty of husband's obligation to Maine merchant).

12. It has been well settled and unquestioned that a court is bound by its own legislature's directives on choice of law. See, e.g., Restatement (Second) of Conflict of Laws $\S 6(1)$. This paper necessarily questions that position.

13. von Mehren \& Trautman, supra note 1, at 237-327.

14. Cf. People v. One 1953 Ford Victoria, supra note 11. 
would come to perceive multistate considerations and ultimately be prepared to allow such considerations to overcome domestic-law interests. Perhaps within the United States the early thinking about choice of law was so dependent on notions of territorial sovereignty, possibly influenced by Huber, that our thinking too tended to stress the clash and to ignore the interdependence of the constituent states. Story certainly drew heavily on territorial theories, ${ }^{15}$ although it is most unlikely that he himself, especially in light of his opinion for the Court in Swift $v$. Tyson,${ }^{16}$ could be charged with denigration of what we today think of as the multistate, or more general, interests of the constituent states.

However the history may cut, the modern position is anomalous. A look at the decisions of American courts suggests the curious conclusion that we see the needs of a multistate order more clearly in the international arena than in the interstate arena. Quite recently, the Supreme Court itself has shown solicitous appreciation of the special demands of international order. In The Bremen $v$. Zapata Off-Shore Company, ${ }^{17}$ the Court rejected the lower court's assumption of jurisdiction-which it thought was compelled by earlier Supreme Court decisions-in a case in which the parties to an international contract of towage had stipulated for litigation in London. Much could have been said for the assumption of jurisdiction in favor of the American plaintiff in the particular case, but the Court seemed to regard as decisive the demands of the international business setting in which the controversy arose: ${ }^{18}$

\begin{abstract}
For at least two decades we have witnessed an expansion of overseas commercial activities by business enterprises based in the United States. The barrier of distance that once tended to confine a business concern to a modest territory no longer does so. Here we see an American company with special expertise contracting with a foreign company to tow a complex machine thousands of miles across seas and oceans. The expansion of American business and industry will hardly be encouraged if, notwithstanding solemn contracts, we insist on a parochial concept that all disputes must be resolved under our laws and in our courts.
\end{abstract}

Similar regard for the special demands of international order was shown in a case involving a stipulation for arbitration in an international transaction, and

15. For evaluations of Story, see Lorenzen, Story's Commentaries on the Conflict of Laws-One Hundred Years After, 48 HARv. L. Rev. 15 (1934); Nadelmann, Some Historical Notes on the Doctrinal Sources of American Conflicts Law, in Ius et Lex: Festgabe zum 70. Geburtstag von Max GutzWILLER 263, 272-276 (1959); Nadelmann, Joseph Story's Contribution to American Conflicts Law: A Comment, 5 AM. J. Legal Hist. 230 (1961).

16. 41 U.S. (16 Pet.) 1 (1842) (". . . the true interpretation and effect [of contracts and other instruments of a commercial nature] are to be sought, not in the decision of local tribunals, but in the general principles and doctrines of commercial jurisprudence. . . The law respecting negotiable instruments may be truly declared in the language of Cicero . . . to be in a great measure, not the law of a single country only, but of the commercial world.").

17. 407 U.S. 1 (1972); see, e.g., Nadelmann, Choice-of-Court Clauses in the United States: The Road to Zapata, 21 Ам. J. СомP. L. 124 (1973).

18. 407 U.S. at $8-9$. 
again multistate considerations overcame strong claims for American judicial jurisdiction designed to vindicate federal-securities-law policies of protecting investors. ${ }^{19}$

The familiar American cases involving international conflict of laws also represent less a conflict between jurisdictions than a serious striving for rules that meet the demands of the international order. A list of those cases, ${ }^{20}$ proceeding roughly chronologically, would include Cammell v. Sewell, ${ }^{21}$ Hope $v$. Brewer, ${ }^{22}$ Hutchison v. Ross, ${ }^{23}$ Lauritzen $v$. Larsen, ${ }^{24}$ and Siegelman $v$. Cunard White Star Ltd. ${ }^{25}$ Apart from Hutchison v. Ross (which should have been decided the other way and would be today on proper analysis of the other jurisdiction's concerns ${ }^{26}$ ), the reason for the decisions seems related less to shared concerns or multistate concerns of the particular concerned jurisdictions than to an appreciation of the general needs of order, system and justice in international transactions, without regard to any particular idiosyncracies of the two jurisdictions involved. A Justice Traynor dealing with any of these cases need not have strained to find multistate policies of the forum in order to justify rejection of the forum's domestic law. One dares to suppose that he would simply have consulted all of the experience to be found in judicial or other materials, of any or all states, and proceeded with caution and intelligence to a reasoned solution of the novel multistate problem presented. Surely all of these cases are better described that way than as examples of a complex accommodation of the special policies, albeit including their multistate policies, of the concerned jurisdictions. I cannot believe that Cammell $v$. Sewell

19. Scherk v. Alberto-Culver Co., 417 U.S. 506 (1974); see Note, International ArbitrationExtraterritorial Application of United States Securities Lau's Denied; Arbitration Clause in Investment Contract Enforced, 16 Harv. INT. L.J. 705 (1975).

20. Babcock v. Jackson, 12 N.Y.2d 473, 191 N.E.2d 279 (1963), is of course also an international case, but it does not involve subordination by a concerned jurisdiction of its own rule.

21. 5 Hurl. \& N. 728 (Exch. Ch. 1860) (sale, under Norwegian law, of timber on board ship that foundered in Norway upheld when timber brought to England, although the consignees of the timber and the purchaser in Norway were English). Although this is an English case, it has become so much a part of American conflicts teaching and thinking that $I$ have no hesitation in asserting that the case has been adopted here and is properly included in a list of "American" cases. It provides the basis for Restatement (Second) of Conflict of Laws $\$ 146$, ill. 1 ; $c f$. id. $\S \S 245,247$, ill. 2 .

22. 136 N.Y. 126, 32 N.E. 558 (1892) (New York testator's gift to establish charitable trust in Scotland upheld, although establishment of such a trust in New York would have been invalid for indefiniteness of beneficiaries and violation of the Rule Against Perpetuities); see von Merren \& Trautman, supra note 1 , at 309 q.3.

23. 262 N.Y. 381, 187 N.E. 65 (1933) (Quebec domiciliary's revocation of New York inter vivos trust, in violation of Quebec rule against alteration of antenuptial agreement, upheld under New York law).

24. 345 U.S. 571 (1953) (Jones Act inapplicable to Danish seaman on board Danish ship under Danish articles who had signed on in New York).

25. 221 F.2d 189 (2d Cir. 1955). See text at note 55, infra.

26. But cf. Wyatt v. Fulrath, 16 N.Y.2d 169, 211 N.E.2d 637 (1965). See generally R. WeinTraub, Commentary on Conflict of Laws 342-45 (1971). 
or Siegelman or Lauritzen purports to proceed from, or be confined by, the policies respectively of England and Norway, England and New York, or the United States and Denmark. The approach undertaken, and the rules announced, are appropriate to and proceed from an understanding of the needs of an international order and reflect an effort, unilaterally as it were by the national forums involved, to contribute to an international body of law applicable to all international cases, although-as is explicit in each case-the law would yield in the face of a strong policy in a concerned jurisdiction. ${ }^{27}$

It seems clear, however, that even if such a body of private international law is developing internationally, there would be substantial apprehension about transposing any such developments to the interstate arena, to the extent that it was seen as being independent of the various concerns of the particular states involved. In interstate conflict of laws, we have become accustomed to pronouncements by the Supreme Court that, subject to constitutional restraints, conflict of laws is a matter left to the states. Most current writing, and the opinion of eminent scholars who have recently addressed the problem, in particular Professors B. Currie and D. Cavers, ${ }^{28}$ concur. At bottom is an assumption that the appropriate allocation of law-making competence in our federal system, finally secured after interminable confusion by Erie Railroad $v$. Tompkins, requires that we restrict our solutions of choice-of-law problems within the United States to the materials found in state law, unless the indicated solution is so capricious or irrational that Constitutional sanctions are appropriate.

I disagree, but in doing so I think it is important first to trace the developments since Erie of the federal common law and to insist on a particular attitude about those developments which $I$ think is indispensable before this experience can be argued to be appropriate and helpful for the general problem of choice of law.

\section{III}

I start with the view that a good deal of the surprise and associated alarm at repeated, and apparently unpredictable, identification by the Supreme Court of new areas for the development of federal common law have been, or ought at least to have been, put to rest by Judge Friendly. His acute perception is that a Hegelian process of synthesis is involved, with Swift $v$. Tyson the

27. See, e.g., Siegelman v. Cunard White Star Ltd., supra note 25 (“. . . we express no opinion on what result would follow if we had stronger policies at stake"). Comparable indications are to be found in Cammell v. Sewell, supra note 21, and Lauritzen v. Larson, supra note 24.

28. E.g., D. Cavers, The Choice-of-Law Process $216-224$ (1965), although federal law binding on state courts is not here directly addressed. But see Baxter, Choice of Law and the Federal System, 16 Stan. L. Rev. 1 (1963); Horowitz, Toward a Federal Common Law of Choice of Law, 14 U.C.L.A. L. REv. 1191 (1967). 
thesis, Erie the antithesis, and the new federal common law the synthesis. ${ }^{29} \mathrm{~A}$ proper understanding of this wisdom, I believe, could put some of the less cautious statements of the Supreme Court in perspective. ${ }^{30}$

Federal common law, like all federal law, should be seen as building on and supplementing the primary law in our system generated by the states; federal common law differing from state law needs to be justified by specific federal requirements left unsatisfied by state law and ought to depart from state law only to the extent of these specifically identified requirements. To suggest a clear example, the seminal decision in Clearfield Trust Co. v. United States $^{31}$ seems correct in releasing the courts from an obligation flowing from Erie to follow state law willy-nilly to decide "the rights and duties of the United States on commercial paper which it issues." The decision seems clearly wrong, however, in proceeding to formulate a substantive rule of federal law differing from what was doubtless the law of almost all states, without a showing that the rule responded to particular federal needs left unsatisfied by state law or not taken into account in the balance of policy struck by the state rules. To substitute a different judgment on a question of law continuously faced in state law $^{32}$ without demonstrating that the national setting of the question introduced new considerations not relevant in the state context is unwarranted and antithetical, I believe, to a proper formulation of federal law. In the particular case, given the broad uniformity of state law and the urgency of ready acceptance by existing commercial channels of federal funds designed to revive the economy, the creation of a different rule for federal checks that would seem to require separate handling of such checks appears capricious and inconsistent with the specific purpose of the federal program involved and with more general federal interests to work with state law and to leave it undisturbed particularly when such a broad measure of uniformity existed among the states.

What might be described as an antithesis to the Clearfield thesis, the decision in Bank of America National Trust $\mathcal{F}^{2}$ Savings Assn. v. Parnell, ${ }^{33}$ is subject to comparable analysis. There the Court, in dealing with a question of the burden of proof of good faith as between the holder and transferee of government bonds, asked, it seems properly, whether the floating of such bonds

29. Friendly, In Praise of Erie-and of the New Federal Common Law, 39 N.Y.U. L. Rev. 383, 421 (1964).

30. Indeed, as is elaborated in the text that follows, the broadness of some of the early "fed. eral common law" decisions such as Clearfield (described in text at note 31 infra) and Parnell (described in text at note 33 infra) might themselves be seen in Hegelian terms, with synthesis now beginning to emerge.

31. 318 U.S. 363 (1943).

32. The Court appears to ground the federal rule on its view of a proper balance of the position of the drawee and the acceptor of a forged instrument: ". . [ [W]e do not think that he who accepts a forged signature of a payee deserves that preferred treatment." Id. at 370 .

33. 352 U.S. 29 (1956). 
"might somehow or other be adversely affected by the local rule of a particular State regarding the liability of a converter . . . It concluded that any such federal impact was "far too speculative, far too remote to justify the application of federal law to transactions essentially of local concern." Given again the broad uniformity of state law on the issue and the fact that the issue is one of balancing considerations of fairness as between two innocent parties, an issue continuously faced in a variety of state-law contexts, the result in using state law seems unexceptionable, so long as no federal need to depart from that rule appeared. The language of the Court, however, can be read as suggesting some impropriety in subjecting these "transactions essentially of local concern" to federal law. This observation seems to me an implicit bow to Erie that is unfortunate; if a federal need to depart from state law could be shown, the formulation of a federal rule would be not only proper but desirable. One might argue, for example, that a federal rule putting the burden on the holder of the paper might be justified if these bonds had been designed to serve as a substitute for currency, so that freer transferability of the bonds would be promoted. If that were the view, there would still be a question whether federal law ought to be constructed that involved departure from a well-settled rule of state law and whether separate treatment of these bonds would disrupt other transactions in the particular banking channels involved-which appears at least less likely than requiring the separate treatment of government checks, as in Clearfield. If, on the other hand, the bonds were designed to encourage investment, a rule protecting the holder and putting a greater burden on the transferee would plainly be justified, so that the specific federal purpose would clearly indicate use of the state rule and leave no further issues to be faced.

That the Supreme Court may today be more ready to steer a middle course, perhaps synthesizing Clearfield and Parnell, is suggested by a pair of cases involving federal savings bonds purchased with community funds. In Free $v$. Bland, ${ }^{34}$ a federal interest in successful sale of these bonds as an aspect of management of the national debt was found sufficient to override state requirements that the form required to pass community property to the surviving spouse was a testament complying with usual requirements of the Statute of Wills. There was, it might be observed, a satisfactory surrogate for a will in the formalities and evidence entailed in the purchase of the bonds. On the other hand, that same federal interest was insufficient, in Yiatchos $v$. Yiatchos $^{35}$ to override the property interests that would be assured to the surviving spouse under state community property law. These cases might well be seen as ones in which significant local concerns were respected where they existed, but where none existed, or the concerns could be regarded as having

34. 369 U.S. 663 (1962).

35. 376 U.S. 306 (1964). But cf. Wissner v. Wissner, 338 U.S. 655 (1950). 
been met but in a way more consistent with federal needs, federal law prevailed.

If, then, federal common law becomes a modest way of releasing courts from an obligation to follow state law in order to vindicate identifiable federal concerns which cannot be accommodated satisfactorily within the body of relevant state law, it would be a useful vehicle for further development of choice of law within the United States. Much of what Professor von Mehren and I have sought to explain as a concerned jurisdiction's subordination of domestic policy to its own multistate concerns-and often the explanation seems adequate enough for the case-could then be seen as being grounded ultimately in a body of general law common to all states which, if it is necessary to find a source of that law to satisfy Holmes' Austinian rejection of the brooding omnipresence in the sky, is federal common law.

I shall not here dwell on the constitutionality of such a conception; should it be decided that such a development is desirable, it would not be overly difficult to find constitutional sanction for it, whether one sought specific text, ${ }^{36}$ or, as has often been sufficient and eminently sound, implication from the federal scheme. ${ }^{37}$ In light of the authorities, it must be concluded categorically-although for many it is hardly an obvious proposition-that federal common law can be created by judges when analytically a federal concern exists; the Constitution not only does not stand in the way but in spirit and

36. Both the Full Faith and Credit Clause and the fourteenth amendment are available; see Baxter, supra note 28. Each explicitly authorizes legislation. Of the two, the Full Faith and Credit Clause is perhaps more appropriate, in light of its place in the Constitutional scheme. See W. Cook, The Logical and Legal Bases of the Conflict of Laws 90-107 (1949); cf. Jackson, Full Faith and Credit-The Lawyer's Clause of the Constitution, 45 Colum. L. REv. 1 (1945).

37. Adjustment of the competing interests of two states or of their citizens engaged in multistate transactions is as "intrinsically" a federal problem as the resolution of interstate water disputes, see Hinderlider v. La Plata River \& Cherry Creek Ditch Co., 304 U.S. 92 (1938) ("whether the water of an interstate stream must be apportioned between the two States is a question of 'federal common law' upon which neither the statutes nor the decisions of either State can be conclusive," per Brandeis, J., on the same day as his opinion for the Court in Erie), disputes involving international affairs, see Banco Nacional de Cuba v. Sabbatino, 376 U.S. 398 (1964) ("The problems surrounding the act of state doctrine are, albeit for different reasons, as intrinsically federal as are those involved in water apportionment or boundary disputes."), or those involving maritime questions touching navigable waters that have not been brought within the reach of the commerce clause, see Note, From Judicial Grant to Legislative Power: The Admiralty Clause in the Nineteenth Century, 67 HARv. L. REv. 1214 (1954); Illinois v. City of Milwaukee, 406 U.S. 91 (1972) ("When we deal with air or water in their ambient or interstate aspects, there is a federal common law ....") In these instances federal common law has developed without Congressional action and for the most part in the absence of specific article I delegation of power to Congress. Although Full Faith and Credit should be enough, see note 36 supra, federal common law may be a more comfortable vehicle until we better understand the line-or that there is no line-between federal common law and constitutional law. Cf. Monaghan, Foreword: Constitutional Common Law, 89 HaRv. L. Rev. 1 (1975). 
intendment has been found to inspire rather than to inhibit the growth of federal common law. ${ }^{38}$

It seems to me that the development of a conception that a judge, whether in a state or in a federal court, was free to consult, and to find authority in, a body of law distinct from the law of the particular states involved in a conflicts dispute would go far toward removing some of the most troublesome aspects of functional analysis as it is now practiced and promote an atmosphere conducive to a sounder development of the field. To revert to Bernkrant, Justice Traynor would not need to be confined to the multijurisdictional policies of California, nor to "shared" policies of California and Nevada, to explain how the California court can restrict the scope of California domestic law. He would instead be speaking as a state judge exercising national authority, which more easily explains why it is relevant to consider the shared policies of California and Nevada-even if the California legislature had sought to make that approach irrelevant-and why he is not only free to weigh the strength of the California and Nevada concerns but indeed is under a duty to do so and to reach a solution which accommodates those concerns with the needs of the multistate order.

This understanding that the state court ultimately exercises federal authority in conflicts cases would also far more easily explain why some of us disagree with the most recent guest-statute decision of the New York Court of Appeals. In the Neumeier case, ${ }^{39}$ New York refused to impose liability in an action involving a New York driver, an Ontario guest passenger, and an accident in Ontario. Had the guest passenger come from New York, the New York driver would have been held responsible whether the accident occurred in New York or in Ontario. ${ }^{40}$ On a view of the problem as one involving only the concerns of New York or Ontario, it is understandable that the New York judge might believe he is being asked to extend the benevolence of New York law, at the expense of New York drivers, to the whole world. ${ }^{41}$ Viewed in the context of a multistate order, however, in which guest statutes are increasingly the exception rather than the rule and on analysis embody obsolescent policies-which at the height of their power undoubtedly were to protect Ontario drivers and their insurers and quite certainly not particularly to deny recovery to Ontario plaintiffs negligently injured even if by an Ontario driver-the picture is vastly different. In this setting, the obvious differ-

38. See note 37 supra.

39. Neumeier v. Kuehner, 31 N.Y.2d 121, 335 N.Y.S.2d 64, 286 N.E.2d 454 (1972); see Trautman, Rule or Reason in Choice of Law: A Comment on Neumeier, 1 VT. L. Rev. 1 (1976).

40. Babcock v. Jackson, 12 N.Y.2d 473, 191 N.E.2d 279 (1963).

41. See Reese, Choice of Law, 71 Colum. L. Rev. 548, 563 (1971) ("Was the New York rule really intended to be manna for the entire world?"), quoted with approval by Chief Judge Fuld in his opinion for the court in Neumeier v. Kuehner, 31 N.Y.2d 121, 130, 335 N.Y.S.2d 64, 71, 286 N.E.2d 454, 458-59 (1972). 
entiation between Ontario and New York plaintiffs is also a consideration; to avoid the appearance of invidious discrimination, ${ }^{42}$ it should require a strong relevant Ontario policy to warrant departure from the multistate norm-and indeed the norm of Ontario for cases not within the driverprotecting policies of its guest statute-of recovery for negligently caused injury. ${ }^{43}$ In short, New York should not regard itself as being asked to "extend" the advantages of New York law to the resident of a jurisdiction which affords less protection to the victim of an automobile accident. It should not be guided by questions of whether it was "advancing" the interests of New York or of New Yorkers, an approach that tends to become parochial and demeaning in this context. If it saw itself as exercising national authority, it would consider the demands of the multistate order, ${ }^{44}$ the extent to which departures from the normal expectations in a multistate case are justified by strong and legitimate local policy, and the basic policies required for a proper functioning of a multistate order. Those policies would at least include policies to shield multistate transactions from capricious interference by rules lacking significant policy bases and to foster rules that treat like cases alike, distinguishing parties and cases from each other only on the basis of significant local policy that is relevant to the distinctions made between cases.

Indeed, if one looks at many of the approaches to solution of cases of true conflict that have been urged recently, it may be more clear why it might be quite salutary to conceive of these approaches as having their footings securely in a federal common law of choice of law. Professor Baxter's article, ${ }^{45}$ which discusses the need for recognition that choice of law is federal together with his "comparative-impairment" approach, effectively demonstrates the strength of this observation. I agree with him, although not entirely with his particular approach, and seek to renew the argument that all such approaches

42. See Bergan, J., dissenting in Neumeier v. Kuehner, 31 N.Y.2d at 132, 335 N.Y.S.2d at 73 , 286 N.E.2d at 460.

43. See Trautman, supra note 39 .

44. I must concede that the multistate order involved in Neumeier is not interstate but international. To the extent, then, that I am pressing for a federal-common-law footing for choice of law in Neumeier, I need to acknowledge that the international context may differ from the interstate context. To an undefined extent, $c f$. Mr. Justice Frankfurter, concurring in Wilburn Boat Co. v. Fireman's Fund Insurance Co., 348 U.S. 310, 321,323 (1954) ("Is it to be assumed that were the Queen Mary, on a world pleasure cruise, to touch at New York City, New Orleans and Galveston, a Lloyd's policy covering the voyage would be subjected to the varying insurance laws of New York, Louisiana and Texas?"), a federal-common-law basis for horizontal choice of law is more justified in the international context. $C f$. Banco Nacional de Cuba v. Sabbatino, 376 U.S. 398 (1964). The proper content of a federal-common-law rule of horizontal choice of law is more readily formulated, on the other hand, when the substantive-law premises of the various concerned jurisdictions are similar; that is likely to occur more frequently in interstate than international cases, although I believe the Canadian experience with guest statutes so closely parallels our own that it is excusable if we deal with Neumeier as an interstate case, just as we have tended to do with Babcock v. Jackson, supra note 20.

45. Baxter, supra note 28. 
will be nurtured by growth in federal soil. For example, although Professor Cavers professes a desire to have his principles of preference subject to the restraints of the forum's legislature, ${ }^{46}$ it is not clear why they would not be given added strength by such a conception. That seems so particularly to the extent that those principles would guide a concerned jurisdiction facing a true conflict toward favoring a higher standard of conduct or financial protection over its own lower standard ${ }^{47}$ or a lower standard when its standard is higher. ${ }^{48}$ The considerations of fairness, of fulfilling expectations, and of avoidance of capricious results, all of which support such guidance, would it seems be far more comfortably found in a general attitude, derived by comparative study of the law of many jurisdictions about the proper attitude toward those considerations, than in the forum's policy alone. Presumably much the same could be said, but even more tellingly, of Professor von Mehren's and my suggestion that emerging law can be favored and regressing law disfavored, ${ }^{49}$ of Professor Leflar's "better-law" approach, ${ }^{50}$ and indeed of all approaches seeking to weigh or assess competing policies, including all approaches favoring validation, ${ }^{51}$ whether as a result of alternative reference or of party autonomy or more generally. All of these reflect efforts of concerned jurisdictions, by subordinating local views of substantive policy, to accommodate their law to, and mesh it more satisfactorily with, the needs and policies of other jurisdictions, which in turn are also concerned with multistate transactions and prepared to yield to a multistate order. If that is so, the contours and content of the multistate law that emerges can, I believe, be better defined by considerations drawn from the overarching multistate order than ones drawn from but confined by the particular views of the jurisdictions concerned in a given multistate situation.

\section{V}

This suggestion of a multistate law as a possible source of rules for choice-of-law problems is perhaps simply another way of expressing an earlier suggestion of multijurisdictional rules specially fashioned to the occasion. Once, however, the source of such multijurisdictional rules is seen as the overarching multistate order of the federal system, so that the rules are not

46. See D. Cavers, supra note 28 , at 218 .

47. As seems possible with Principle I (id. at 139) (as his first illustration would suggest when Arizona is the forum, id. at 141-142); Principle III (id. at 159); and Principle IV (id. at 166).

48. E.g., Principles II (id. at 146) and V (id. at 177).

49. See especially von Mehren \& Trautman, supra note 1 , at 377.

50. See, e.g., R. Leflar, Conflicts Law: More on Choice-Influencing Considerations, 54 CaLIf. L. REv. 1584 (1966).

51. Even Restatement (Second) of Conflict of Laws cannot avoid this process of comparative assessment of policy, although it surfaces primarily in areas in which it is so well established that its existence cannot be denied. See, e.g., id. $\S \S 187,203,270$, as well as $\S 6(2)(\mathrm{a})$, (d), (e), and (f) and accompanying comment. 
confined by being strictly tied to the law and policy of the jurisdictions concerned, it is perhaps possible to envisage a different mechanism entirely for the multistate problem. We have become so accustomed by tradition and theory to ideas of conflict, choice and selection that other possible mechanisms have not commended themselves. The substance today, however, of much of "choice of law," or, more felicitously, "multistate law," does seem better understood in terms of a mechanism other than one of selection or choice. The process seems rather to be one of the use of what, for lack of a better introductory term, I shall for the moment call a normal rule, to be overridden, however, when a concerned jurisdiction has a strong relevant policy in conflict with the "normal" rule. Most "conflicts" rules in the areas in which the normal policies of the law tend toward validating or facilitating private ordering-in marriage, contract, property and trust, for example - could better be expressed in terms of validation of the arrangement privately undertaken except when some jurisdiction with a strong policy, typically one of protection of one of the parties to the transaction but sometimes of protection of other interests, would strike down the arrangement. Examples of this attitude are clear in most formulations of rules with respect to the validity of a marriage, and the cases clearly uphold marriages except when strong relevant policies-usually of the domicile of the parties-stand in the way. ${ }^{52}$ The same phenomenon occurs in contracts and trusts. In Bernkrant $v$. Fowler, the decedent's promise to make a will is upheld because the local protective policy is not strong enough to interfere; ${ }^{53}$ in Shannon v. Irving Trust Co. ${ }^{54}$ the settlor's stipulation for his domicile's law, which would validate his trust, is upheld because there is no policy basis for invoking the invalidating New York Rule Against Perpetuities; in Siegelman v. Cunard S.S. Co.,$^{55}$ the parties' stipulation for English law is upheld, the Court of Appeals for the Second Circuit making it plain, however, that the result might be different if stronger policies were at stake.

Of course the holdings of these cases can be expressed in terms of selection between the "laws" of two concerned jurisdictions. They can be expressed in those terms even more agreeably if those "laws" include the multijurisdictional policies of those jurisdictions. But it is also possible, and for some situa-

52. One need go no further than Restatement (Second) of Conflict of Laws $\$ 283$ (Validity of Marriage) and especially $i d$. Comments $b, i$, although the cases in the area have always been un ruly precisely because of an attitude, sometimes explicit, that a "normal" attitude of validation ought to prevail unless the domicile had a strong policy on which it was prepared to insist. See, especially, Fisher v. Fisher, 250 N.Y. 313, 165 N.E. 460 (1929), and In re May's Estate, 305 N.Y. 486,114 N.E.2d 4 (1953).

53. See text following note 5 supra.

54. See note 11 supra.

55. See note 25 supra. A general statement suggesting the offset of protective policies against policies favoring the integrity of transactions was made by Professor Cavers in Cavers, $A$ Critique of the Choice-of-Law Process [sic]: Addendum 1972, 17 HARv. INT'L L.J. 652 (1976). 
tions it may be more helpful, to express these holdings in terms of normal rules of "multistate law" which operate except when strong policies are at stake.

Whether this conception is applicable beyond the realm of planned transactions may be more problematical, but that is a question worth exploring for a moment. If, as I have suggested elsewhere, ${ }^{56}$ it is helpful to ask in guest statute cases whether shared views favoring deterrence and compensation ought to apply or, in the particular circumstances, ought not to because a strong policy exists justifying departure from those shared policies, perhaps a different content for what is the "normal" rule has been supplied but, with that variation, the same process can be said to be at work.

\section{VI}

If this conception of multistate law came to be accepted, it would provide a way of seeing interrelationships between choice of law in general (horizontal choice of law) and the balance between state and federal law in our federal system (vertical choice of law) that have at best been only dimly perceived as yet. It might in addition give support to a more balanced view, suggested earlier, of the way in which federal common law ought to develop.

In vertical choice of law, as has been intimated and will be explained more fully below, it is often more responsive to the demands of the federal system, as that system has come to be understood, to conceive of federal law operating only as a limit or boundary, a floor or a ceiling, on state law. That seems inevitably so with a federal law that functions interstitially and, as has been suggested, in principle should be created only in response to, and to the extent of, federal requirements not taken into account in the formulation of the state law rules. It is for comparable and perhaps more obvious reasons that federal constitutional law often takes the form of limits or boundaries on state law; this phenomenon has recently been highlighted in the series of cases defining the First Amendment's effect on state laws of defamation: federal law provides a limiting framework beyond which state law may not go but within which state law is free to provide as it will. ${ }^{57}$ To the extent that federal common law can also be understood as operating, or as being more rational if it did so operate, as a boundary on state law, we would have a phenomenon parallel to that suggested for horizontal choice of law. Thus federal common law would grow out of but at times enlarge upon or exclude the normally applicable state law in the same way as it has been suggested that a concerned

56. E.g., Trautman, supra note 39 , at 21 .

57. See, e.g., Gertz v. Robert Welch, Inc., 418 U.S. 323 (1974). For a thoughtful treatment of the potential of federal common law as a boundary on state law, see M. Broad, "Incorporating State Law into the Federal Structure: Floors and Ceilings in State-Federal Accommodations" (unpublished manuscript in Harvard Law School Library), on which the following discussion draws heavily. 
jurisdiction's law might diverge from and in instances of legitimate and strong policy exclude the normally applicable multistate law, law which itself is formulated from the norms found in state law. ${ }^{58}$

In the discussion that follows, a brief attempt will be made to view the interrelation of horizontal and vertical choice of law from this perspective. At the outset, however, it may help to draw further illustration from vertical choice of law, focusing on its potential development as a law primarily providing boundaries-floors or ceilings-on state law.

It has already been suggested that the Clearfield case, ${ }^{59}$ in carving out an area for the possible development of federal law independently of a perceived need to depart from state law, misconceived the proper operation of federal common law. In its preoccupation with the problem of explaining why Erie did not control, the Court failed to take the necessary further step of asking in what ways, if any, state law, which should be seen as the foundation upon which federal law builds and to which federal law forms an exception, needed revision or rejection in order to serve the federal purposes. Such an approach would have been particularly commendable in the context of Clearfield. The Government was using established commercial channels and arrangements for the purpose of carrying out its fiscal functions, and there was a particular need to see to it that the private channels availed of were not unduly disrupted by the injection of federal transactions. Hence, it should have been

58. In a sense, a more strict parallel would exist if one supposed that, as a practical matter, federal-common-law rules and the proposed multistate rule operated only as occasional limits on state law. Such a view would follow from the fact that in the case of federal common law and the vertical choice it often is sufficient-and for that reason customary-to think in terms of a choice between a federal-common-law rule and the rule of a particular state. This analysis does not hold, however, if there is more than one concerned state; it is, therefore, sufficient only if there is no horizontal choice-of-law problem.

If a horizontal choice-of-law problem exists, it should be treated on the basis suggested in the text: should the normal or usual rule in the legal universe of the various jurisdictions concerned be departed from because of a strongly-held divergent view in a jurisdiction with a relevant concern? Where the answer is yes, a basis for possible departure from multistate law is provided. Thus, one limit or boundary to the operation of multistate law occurs when the problem is of local concern and the primarily concerned state legitimately holds a strong policy which it desires to assert. Another limit or boundary to multistate law occurs when the problem is of national concern and there are special federal requirements not satisfied by multistate law or if the particular state primarily concerned has deviant or parochial views.

This suggestion may pose a threat to the underpinnings of Klaxon Co. v. Stentor Elec. $\mathrm{Mfg}$. Co., 313 U.S. 487 (1941), directing federal diversity courts to follow the choice-of-law rules "prevailing in the states in which they sit." $I d$. at 494 . The basic command of Erie, however, was that federal law should not be created, in the interest-I believe-of reducing uncertainty about the rules that apply to primary conduct. Klaxon reintroduced some of that uncertainty by making the federal court "touch base" with the law of the state in which it sat, regardless of whether that place, chosen on the basis of jurisdictional and venue rules that do not address the choice-of-law problem, was the appropriate place to start. If the "state law" to be applied under Erie were seen as the multistate law proposed in the text, to be subordinated to a particular state's law only on the basis I have suggested, Erie's purpose would come far closer to being realized than under Klaxon.

59. See text following note 31 supra. 
inevitable to think in terms of altering the state-law arrangements and understandings as little as possible and to fashion different federal rules only when necessary to effectuate the federal purpose. Instead, as noted above, ${ }^{60}$ the Court blandly substituted its own view on a question that seems to be peculiarly fit for state law: the relative equities as between the drawer bank and the acceptor of a forged indorsement.

In Clearfield then, although federal power may well be said to exist, that abstract proposition ought not to have allowed the Court to proceed to its own view on a question settled in state law and not disruptive of-indeed in context quite consistent with-the federal purpose to pump money into the economy. This is the proper view of the federal law to be fashioned under Clearfield, I think; under this model, state law would be taken, whatever its content, except when the federal purpose requires a limit on what state law provides. In another context, which I think is susceptible of the same analysis, the Court did just that, saying that "the congressional purpose can best be accomplished by application of settled state rules . . . so long as it is plain, as it is here, that the state rules do not effect a discrimination against the Government, or patently run counter to the terms of the Act." ${ }^{1}$ And in describing Congressional adoption of state law to determine the liability of the Government under the Federal Tort Claims Act, the Court observed: ${ }^{62}$

... It is evident that the Act was not patterned to operate with complete independence from the principles of law developed in the common law and refined by statute and judicial decision in the various States. Rather, it was

60. See note 32 supra.

61. Mr. Justice Black, speaking for the Court in Reconstruction Finance Corp. v. Beaver County, 328 U.S. 204, 210 (1946). Compare the language of Mr. Justice Harlan, speaking for the Court in DeSylva v. Ballentine, 351 U.S. 570, 581 (1956), adopting "the ready-made body of state law to define the word 'children'" in the Copyright Act; a State could not "use the word 'children' in a way entirely strange to those familiar with its ordinary usage, but at least to the extent that there are permissible variations in the ordinary concept of 'children' we deem state law controlling."

62. Richards v. United States, 369 U.S. 1, 6-7 (1962). That the Court, after lengthy yawing. may now be on course is a view one could take of its recent opinion in Miree v. DeKalb County, Ga., 97 S. Ct. 2490 (1977), infra note 75. Compare, generally, HART AND WEChSLER's THE FEDERAL Courts and the Federal System 470-471 (2d ed., P. Bator, P. Mishkin, D. Shapiro \& H. Wechsler 1973).

To the extent, however, that federal common law serves only to modify state law when federal interests demand, a significant problem of federal jurisdiction may be created. Such an approach might make it unwieldy to attempt distinctions between claims grounded in federal law and those grounded in state law. If such distinctions are significant, the conception of a case "arising under . . the Laws of the United States," U.S. Const. art. III, $\S 2$ (now held to comprehend all federal common law cases, Illinois v. City of Milwaukee, Wisconsin, 406 U.S. 91 (1972), with the possible exception (the City of Milwaukee case is arguably in admiralty) of judge-made law in admiralty, Romero v. International Terminal Operating Co., 358 U.S. 354 (1959)) might require re-thinking if such a limited role for federal common law were to be accepted. I think the Constitution is up to the task. Compare Osborn v. Bank of United States, 22 U.S. (9 Wheat.) 738 (1824), with Mr. Justice Frankfurter, dissenting in Textile Workers Union of America v. Lincoln Mills of Alabama, 353 U.S. 448,460 (1957). 
designed to build upon the legal relationships formulated and characterized by the States, and, to that extent, the statutory scheme is exemplary of the generally interstitial character of federal law. If Congress had meant to alter or supplant the legal relationships developed by the States, it could specifically have done so to further the limited objectives of the Tort Claims Act. That is, notwithstanding the generally interstitial character of the law, Congress, in waiving the immunity of the Government for tortious conduct of its employees, could have imposed restrictions and conditions on the extent and substance of its liability.

A clear, although rather esoteric, example of an appropriate occasion for the functioning of federal common law as a boundary on otherwise applicable state law is seen in admiralty ${ }^{63}$ For over half a century, while state law was in the process of abandoning the common law rule under which no action lay for wrongful death (and Congress echoed that process by providing actions for the wrongful death of seamen and of anyone meeting death on the high seas), no federal wrongful death action was available for use in connection with maritime torts to longshoremen within state territorial waters. Admiralty courts, however, responded by "borrowing" the appropriate state wrongful death actions in such situations. This was a "jerry-built" remedy which could not survive as federal maritime tort law grew to be far more generous than the developing state law. By 1959, it was clear that some maritime duties, notably that to provide a seaworthy ship, had surpassed much of state law and that the expedient of borrowing a state wrongful death remedy would not be sufficient if the remedy had to be taken with all its state-law impedimenta -especially the state definitions of duty, contributory negligence, time limitations and the beneficiaries entitled to participate in wrongful death action proceeds. But the Supreme Court stubbornly espoused an idea not unrelated to the "vested rights" theory of horizontal conflicts, which had not yet been completely laid to rest, and held, in The Tungus $v$. Skovgaard, ${ }^{64}$ that when admiralty adopted state law, it took it bag and baggage. Precisely at issue was the question whether the federal duty of seaworthiness was available in an action "borrowed" from the New Jersey wrongful death act. The Court held that it was, but only because, as the Court of Appeals had found, New Jersey would include within the "wrongful act, neglect or default" that was prerequisite to recovery under the New Jersey Act the federal rule of unseaworthiness. New Jersey law was applicable, but it encompassed, through incorporation by reference, the federal duty. Justice Brennan, in a notable concurrence, ${ }^{65}$ insisted that it should not be said that state law incorporated a federal standard but that the state remedy was taken up to complete the re-

63. There has been more experience with federal common law in admiralty than elsewhere, and it is not surprising that rich illustration of methodological possibilities is found there.

64. 358 U.S. 588 (1959).

65. Id. at 597. His opinion, a concurrence on this point, dissented as to reference to state law for determination of possible defenses. 
medy for violation of a federal duty: "It is the federal maritime law that looks to the state law of remedies here, not the state law that incorporates a federal standard of care." But that more manageable notion failed to carry the Court. The next case found the Court asked to approve the borrowing of state law that was more generous than federal law to the longshoreman (and by the same token more burdensome to the shipowner.) State law again prevailed but by a coalition of Justices not unlike some strange Congressional alliance: Justice Stewart, who had written for the Court in The Tungus and was joined there by Justices Frankfurter, Clark, Harlan and Whittaker, was joined this time only by Justice Clark, in holding that state law was applicable with all its incidents. They were, however, also joined by Justice Brennan and the other three who had agreed with him in The Tungus, by compulsion of The Tungus. The other three Justices dissented; Justice Harlan, joined by Justice Frankfurter and, at least on this point, by Justice Whittaker, wrote-in a fine opinion-that state law could not impose a greater duty than that permitted by federal law. Much of Justice Harlan's opinion can be read as saying that federal law provides a boundary-here a ceiling-on the state law, which is otherwise free to operate. Although it may well be that this methodology is not the correct choice for this area of the law, ${ }^{\mathbf{6 6}}$ the technique in the context of what the Court had previously decided seems quite sound and worthy of note.

A regime of federal common law under which the courts-federal or state-draw as heavily as possible upon state law and depart occasionally by limiting that law so as not to exceed certain boundaries, strikes me as being not only congenial to the best traditions of federal law and judicial lawmaking but the most attractive way of realizing the potential of our compli-

66. Perhaps federal law should operate without regard to state law as to the duty involved in these cases, since federal law does so when the injury does not result in death. However, the Court in later reaching that position by deciding, in Moragne v. States Marines Lines, 398 U.S. 375 (1970), that a judicially-created federal wrongful death action does exist, also seemed to suggest, erroneously it seems, that federal law would then also decide other issues including the beneficiaries of the wrongful death action. That issue, as Justice Brennan had-it seems rightly-said in The Tungus, should be governed by state law. That it was Justice Harlan who wrote for the Court in Moragne seems surprising and lamentable, to the extent that all issues now may be governed by federal law, and it is at least as anomalous that Justice Brennan joined the Court in Moragne and thus failed to preserve the very important point about beneficiaries that he had insisted on in The Tungus. David Currie's characterization of some of the earlier part of this story, and other related stories, continues unabated as the apt one. See D. Currie, Federalism and the Admiralty: "The Devil's Own Mess", 1960 Sup. C. REv. 158.

I do not mean to suggest that an approach to federal common law on an issue-by-issue basis will always prove appropriate. It may well be, although I am in no position to assert it, that a "wholesale" approach to federal common law is needed in areas such as the one. identified in Textile Workers Union of America v. Lincoln Mills of Alabama, 353 U.S. 448 (1957). Even there, however, the more mundane issues might find solace if not solution in state law. See, e.g., Local 174 v. Lucas Flour Co., 369 U.S. 95 (1962); UAW v. Hoosier Cardinal Corp., 383 U.S. 696 (1966). Nor do I minimize the conceptual difficulties of such a view in dealing with the "federalquestion" jurisdiction. See note 62 supra; note 79 infra. 
cated hierarchies, federal and state, of judicial law-making authority. And the same can be said of a multistate law to deal with horizontal choice-of-law problems, if that law is seen as functioning unless a strong state law policy forbids. It was, I believe, in this spirit that Mr. Justice Jackson wrote his profound concurring opinion in the D'Oench, Duhme case ${ }^{67}$ shortly after the decision in Erie. In D'Oench, Duhme, involving confusion in the lower courts on the question of which of two states' law was applicable, in an action by the Federal Deposit Insurance Corp., to the liability of an accommodation maker of a note used by a bank to conceal the true state of its assets, Justice Jackson was moved to write a classic essay on federal law-making. The Court, in a regrettably facile opinion by Justice Douglas, had found a federal rule of liability implicit in Congressional establishment of the insurance corporation and "a general policy to protect the institution of banking from such secret agreements." Justice Jackson demanded a fuller explanation and demonstrated with great elaboration the necessity and utility of resort to "the common law" to give content to federal law. "Were we bereft of the common law, our federal system would be impotent." Later in the opinion, he stated clearly a position similar to that taken in this paper. ${ }^{68}$ "No doubt many questions as to the liability of parties to commercial paper which comes into the hands of the [F.D.I.C.] will best be solved by applying the local law with reference to which the makers and the insured bank presumably contracted. . . . But ... [t]he policy of the Federal Act does not seem to me to leave dependent on local law the question whether one may plead his own scheme to deceive a bank's creditors and supervising authorities as against the Corporation."

Like Bernkrant v. Fowler, ${ }^{69}$ the D'Oench Duhme case is one that suggests the concurrence of a variety of fruitful approaches. It would have been a useful occasion to explore the possibilities of a federal influence on harmonizing any conflicting state policies in the case. Justice Frankfurter saw the problem and stated, it seems most helpfully: "Whether the case is governed by the law of one State or the other, or by 'federal common law' drawn here from one State or the other, the result is the same." In my view, that should have been sufficient, so long as it was understood that federal common law might well begin with-and indeed should begin with-but need not end with, or be confined

67. D'Oench, Duhme \& Co. v. F.D.1.C., 315 U.S. 447, 465 (1942).

68. Id. at 470. In fairness, it should be noted that Justice Douglas, on several occasions in which he nonetheless concluded that a federal-common-law rule supplanted any relevant state law, conceded the utility of generous use of state law in giving content to the federal common law. See, e.g., Textile Workers Union of America v. Lincoln Mills of Alabama, 353 U.S. 448, 457 (1957) ("Federal interpretation of the federal law will govern, not state law. . . But state law, if compatible with the purpose of [the federal statutory provision], may be resorted to in order to find the rule that will best effectuate the federal policy. . . . Any state law applied, however, will be absorbed as federal law and will not be an independent source of private rights."); Illinois v. City of Milwaukee, Wisconsin, 406 U.S. 91, 107 (1972).

69. See text following note 5, supra. 
by, the laws of the two States. Even if the F.D.I.C.'s intervention in the transaction created no special problems requiring a distinct federal rule of substantive law, multistate law with federal roots could have effected a choice of law grounded in multistate protective policies that surely should have carried the day as against any possible local policy to protect the accommodation maker. ${ }^{70}$ That is to say, if local choice-of-law policy-contrary to Justice Frankfurter's conclusion-did indicate a difficulty, multistate law could have been found that would have overcome a contrary local policy. In this commercial context, an undifferentiated federal policy to harmonize and make uniform the laws of the several states could have been identified, although of course such a policy is unlikely to be significant as to questions on which our federal system encourages local diversity or is not prepared to impose uniformity in the face of strongly-held local views.

Only if examination of the potential of multistate law proved fruitless would the Court have then come to the question whether the presence of the F.D.I.C. created a new consideration. If it clearly did, a separate federal common law, as enunciated by the Court, would be indicated. It seems to me doubtful that it was necessary to embark on the creation of a new body of law; certainly analogues to the position of the holder in due course would have been discoverable, and use of such analogues would have been better judicial statesmanship.

What, however, is more important in this part of the discussion is the proposition that at either step-recognition of a multistate law grounded in federal common law or formulation of a federal common law rule-it would have been sufficient (and therefore in my view no more was appropriate) to formulate the resulting multistate law or federal common law rule in terms of a floor of protection for the F.D.I.C. below which state law would not be allowed to descend.

Doubtless many other situations can be analyzed in the same way. Perhaps it is enough, however, to conclude with the observation that this approach is one that the Supreme Court has in fact taken, although it may have done so, as Professor Gilmore has observed of early stages of this phenomenon, "almost unconsciously." 71 In the Sabbatino case, ${ }^{72}$ the Court held that federal common law (here clearly a law involving or at least impinging on choice of $\operatorname{law}^{73}$ ) functioned to preclude overly extensive inquiry by state courts into the

70. Certainly if Missouri law came into play only because, upon a failure of proof of Illinois law, Missouri courts would presume the Illinois law to be the same as that of Missouri, only a minimal multistate policy would have been needed to prevail over this Missouri choice-of-law rule. See 315 U.S. at 455.

71. See Gilmore, Legal Realism: Its Cause and Cure, 70 YALE L.J. 1037, 1046 (1961), quoted in Friendly, supra note 29 , at 421 .

72. Banco Nacional de Cuba v. Sabbatino, 376 U.S. 398 (1964).

73. See Henkin, The Foreign Affairs Power of the Federal Courts: Sabbatino, 64 Colum. L. Rev. 805, 809-811 (1964). 
validity of acts of a foreign state. That this federal common law or multistate law might be only a boundary rather than a rule with more contours was clearly suggested, however: "We need not now consider whether a state court might, in certain circumstances, adhere to a more restrictive view concerning the scope of examination of foreign acts than that required by this Court." ${ }^{14}$

Surely there is here the seed of an enormously useful device for making the federal system more workable. The focus on sources of law-making authority that led to Erie and to Southern Pacific v. Jensen ${ }^{75}$ were useful in helping us sort out the problems. But obsession with sources of power misled us into thinking that power was a touchstone for appropriateness. One need not repudiate Erie and Jensen to ask that the focus shift to appropriateness, with a proper bias against federal law unless it is needed. With that new focus, there should be a better prospect for realizing Judge Friendly's beautifully simple and simply beautiful conception of the interworkings of federal and state law.

\section{ConcLusion}

Although the foregoing is intended as a tentative statement, a number of perhaps novel and doubtless controversial premises are involved; with some tredipation, I venture to summarize.

In what I have called horizontal choice of law, we have traditionally begun with "conflicts" among the laws of the states without regard to the general legal climate to which we all nevertheless naturally have reference in our thinking. It is far more natural, I think, for judges and lawyers to make a first approximation to solution of a legal problem on the basis of general learning $^{76}$ and then, in probing into a problem, to try to determine whether

74. 376 U.S. at 425 n.23.

75. 244 U.S. 205 (1917) (striking down state-court application of state law, in that it "work[ed] material prejudice to the characteristic features of the general maritime law or intertere[d] with the proper harmony and uniformity of that law in its international and interstate relations").

Despite regrettable recitals that the United States was not a party and that the suit was in diversity, the Supreme Court in its recent decision in Miree v. DeKalb County, Ga., $97 \mathrm{~S}$. Ct. 2490 (1977), placed major emphasis on the language in Wallis v. Pan American Petroleum Corp., 384 U.S. 63, 68 (1966) ("In deciding whether rules of federal common law should be fashioned, normally the guiding principle is that a significant conflict between some federal policy or interest and the use of state law in the premises must first be specifically shown."). This language states a sound test which, together with the Court's clear examination of the content of federal and state law to ascertain whether sufficient interests existed, should provide a firm basis for future development of federal common law. At the same time, it is to be hoped that discussion of whether the United States is a party, of the basis of jurisdiction, and of the impact on the federal treasury-itself clearly a matter for Congress and not for a court doing justice between individual parties, $f f$. Unted States v. Standard Oil Co. of California, 332 U.S. 301 (1947)-will soon disappear from the judicial literature on federal common law.

76. Cf. H. Hart \& A. Sacks, The Legal Process 27-28 (Tent. Ed. 1958):

. . . [T]he courts of the different states draw upon a common pool of ideas in the decision of cases-except to the extent that their own legislature has directed or their own past decisions require a distinctive mode of disposition. This pool of ideas was, in the first instance, largely although not exclusively an inheritance from England. Putting 
in the particular case there are special factors commanding a different solution.

Intellectual support for this "natural" approach can be found in two developments, both of which are examined in this paper: first, the emergence in horizontal choice of law of mechanisms for subordinating domestic-law policies-through moderate and restrained interpretation of domestic rules or more candidly through such approaches as the recognition of multistate policies or the development of principles of preference; and, second, the concurrent growth, especially in response to Erie, of federal common law. A difficulty with federal common law is that it is still very much in the formative stage; the Supreme Court has not adequately addressed the question of creating a general framework for its development. ${ }^{77}$ It has therefore seemed necessary to make some suggestions about such a framework. It is my position that if those suggestions are found acceptable and if horizontal choice of law comes to be seen as an aspect of federal common law within that suggested framework, much of the current unease in American choice of law might be alleviated.

As I have argued, I think federal common law should develop only in response to identified federal needs not adequately served by state law. Indeed, federal common law can, I think, often take the form simply of limits or boundaries on state law. If such a conception of federal common law is accepted, then I think that horizontal choice of law is an eminently appropriate area to be included within the scope of federal common law. The chief consequence, as I see it, would be to free state judges from local rules that capriciously interfere with multistate transactions and to provide state and federal judges alike with an intellectually congenial way of approaching multistate problems.

It is true that, quite properly, federal common law has been held to be within the "arising under" or "federal-question" jurisdiction of the federal courts. $^{78}$ Choice of law should be no exception, and although a federal common law of choice of law might aggravate whatever problems there are with the appellate case load of the Supreme Court, it is unlikely to add substantially to the business of the lower federal courts. That would be so particularly

aside the special case of Louisiana, American courts all looked predominantly to the English common law, or to so much of it as they believed to be adaptable to American conditions, in shaping their own decisional rules. Over the years, of course, the rules of the courts in different states have developed many points of divergence. But the common pool of ideas has been maintained and refreshed by the teaching of law schools, by the writings of legal scholars, and by cogent opinions of able judges which have won acceptance in courts of other states. This common pool constitutes always a powerful force for homogeneity of legal thought in opposition to the many forces making for heterogeneity.

77. See, however, note 75 supra.

78. Illinois v. City of Milwaukee, Wisconsin, 406 U.S. 91 (1972). 
if it develops as I suggest it should, interstitially and as a check on state choice of law rather than as the normal foundation of a plaintiff's claim arising under federal law, ${ }^{79}$ and if, as I contemplate, this kind of federal common law enjoys far wider application and development by state courts, with guidance at times by the Supreme Court, than has perhaps in general been the case with federal common law.

If these suggestions are accepted, I think we might see choice of law within the United States as a much more manageable and much less esoteric matter than it has at times seemed to be. Judges and lawyers would ask themselves, first, whether there exists a normal or usual way of dealing with a legal problem, informed as we all hope to be by comparative investigation of the law in the legal world to which our states belong. Only after some tentative view was reached, as I suppose judges and lawyers probably do regardless of what the conflicts scholars say, would it then be open to consider the nuances of the particular case. At that point, the existence in some state of a strong and relevant policy that warranted departure from the normal or usual rule would be considered. To a large extent, the only significant contribution of federal common law to this process would be to free state-court judges from any compulsions they might otherwise find in local law to prefer local law or local residents and to provide them with the intellectual equipment needed to justify assessment of the strength of local policy and of the policy of other concerned jurisdictions. Thus, what is contributed by federal common law is essentially an attitude of neutrality and authority to view multistate problems from the perspective of the overarching federal order. That very limited contribution should be sufficient, I think, for removing parochial perspectives that create an illusion of true conflict when on further unfettered analysis a false conflict should be found to exist. That is what I believe Justice Traynor demonstrated in his own fashion in Bernkrant and what Judge Fuld could well have done, albeit reaching the contrary result, in Neumeier.

For situations not in this way reducible to false conflicts, the contribution of federal common law could be more pervasive. For example, as already suggested, ${ }^{80}$ for planned transactions the normal approach would doubtless be one of validation, to give effect to the transaction, unless-and that would be the decisive issue, a manageable and understandable one-a protective or

79. To whatever extent my suggestion would add to the business of the lower courts, already seriously burdened, I can only hope that my approach would further stimulate re-examination of their business. See, e.g., H. Friendly, Federal Jurisdiction: A General View (1973) (urging drastic surgery through a wide array of proposals too numerous to summarize here; among them, however, are severe limitation of the diversity jurisdiction and non-judicial alternatives for F.E.L.A. and Jones Act cases). To the extent that my suggestion of a very limited and truly interstitial federal common law would add to difficulty in deciding whether cases "arise" under state or federal law, I can only say that that is a question that deserves reconsideration. See note 62 supra. See also von Mehren \& Trautman, supra note 1, at 1019, 1054-1058, and note 66 supra.

80. See part V supra. 
other invalidating rule of some concerned jurisdiction ought to be applied. This issue is to be considered from the perspective of, and with authority from, the federal community and not from the local perspectives afforded by the particular concerned states. Thus, in Milliken $v$. Pratt, ${ }^{81}$ pitting a Massachusetts policy to protect married women against policies supporting the security of transactions, à much more complete federal-common-law rule could develop. That rule, while allowing for recognition of a currently vital Massachusetts protective policy, would enable the Massachusetts court-as it did, much to its credit, without any such doctrinal assistance ${ }^{82}$ - to stand back, as it were, and ask about the current strength of the Massachusetts policy as against the multijurisdictional concerns of Massachusetts (and Maine) and the concerns of Maine. To the extent that the emerging choice-of-law rule was contrary to a particular state's choice-of-law rule, it would displace that state rule by force of federal authority or, preferably, would provide federalcommon-law limits on that state rule. ${ }^{83}$

In tort, the operative issue would be whether normal policies of compensation and loss-spreading should be interfered with by such recovery-denying rules as guest statutes, charitable immunity, interspousal immunity, and limitation on the amount of recovery for wrongful death-as to all of which I think it is possible to make quite objective determinations, in most states at least, whether the policies underlying such rules have current strength adequate to justify their application to multistate cases. In any event, local attitudes against such inquiries would not be decisive.

As I have tried to explain, but doubtless will need to elaborate as our thinking and experience grow, federal common law is an analytically sound and intellectually satisfying basis for such developments in American choice of law. How we deal with international choice of law remains a problem, a somewhat different one. Although justification for the extension of federal

81. See note 11 supra.

82. See 125 Mass. 374 at $382-383$ :

In the great majority of cases, especially in this country, where it is so common to travel, or to transact business through agents, or to correspond by letter, from one state to another, it is more just, as well as more convenient, to have regard to the law of the place of the contract, as a uniform rule operating on all contracts of the same kind, and which the contracting parties may be presumed to have in contemplation when making their contracts, than to require them at their peril to know the domicil of those with whom they deal, and to ascertain the law of that domicil, however remote, which in many cases could not be done without such delay as would greatly cripple the power of contracting abroad at all.

83. Thus, for example, a federal choice-of-law rule might emerge-functioning, however, as a limit or boundary on the permissible state choice-of-law rules-under which a state with a currently vital policy to protect a person engaged in a multistate transaction would nevertheless be precluded from asserting its policy, particularly if to do so would unfairly surprise a person in a jurisdiction with relevant and strong countervailing concerns to protect the intregrity of transactions. For another example of the kind of federal rule that might emerge, compare von MEHREN \& Trautman, supra note 1 , at 217-218. 
choice of law to international choice of law is perhaps clearer ${ }^{84}$-and indeed it may already have happened ${ }^{85}$ - the greater dissimilarity in the law and institutional premises usually found in international cases, and the absence of central authority, will often make it impossible to establish for that legal world that a normal or usual rule exists from which justification for departure is to be demonstrated. Be that as it may, I think there may be a number of areas in which there is sufficient consensus on substantive-law issues that we need not be totally unwilling on occasion to attempt a comparable approach in international cases.

84. See note 44 supra.

85. See Henkin, supra note 73 , and text at note 72 supra. 